Original Research Article

\title{
Cell blocks prepared from gynaecologic liquid based specimens: as a source for further ancillary techniques
}

\author{
Kulkarni $\mathbf{S}^{1}$, Manoli $\mathbf{N}^{2}$, Manoli $\mathbf{N}^{3}$ \\ ${ }^{1}$ Dr. Shweta Kulkarni, Senior Resident, Department of Pathology, Indira Gandhi Institute of Child Health, Bengaluru, \\ ${ }^{2}$ Dr. Nandini Manoli, Professor, Department of Pathology, JSS Medical College, A Constituent of JSS University, India, \\ ${ }^{3}$ Dr. Nandish Manoli, Professor, Department of Obstetrics and Gynaecology, JSS Medical College, A Constituent of JSS \\ University, Sri Shivarathreeswara Nagara, Mysuru - 570015, Karnataka, India.
}

Corresponding Author: Dr. Shweta Kulkarni, Senior Resident, Department of Pathology, Indira Gandhi Institute of Child Health, Bengaluru, Karnataka, India. Email: drshwetakulkarni@gmail.com

\begin{abstract}
Background: Cervical cancer is the second most common cancer among women worldwide and leading causes of cancer deaths amongst women. Cell blocks prepared from liquid-based specimens can serve as a useful adjunct and cell blocks can be further subjected for ancillary molecular techniques. Materials and Methods: In the present study 60 cell blocks were prepared from Manual liquid-basedcytology (MLBC) specimen collected in liquid fixative. Results were compared with cytology smears and histopathological correlation was obtained in 19 cases. P16 and Ki67 were used whenever required. Results: In the present study out of 60 cases of cell blocks 10 cases had no deposit. Of the other 50 cases, 7 cases $(14 \%)$ were neoplastic and $43(86 \%)$ were non-neoplastic. The sensitivity and specificity of cell block, LBC and CPS were $75 \%$ and $93 \%, 66 \%$ and $84 \%, 50 \%$ and $70 \%$ respectively for neoplastic lesions of cervix. Concordance Rate of $\mathrm{CB} /$ Histopathology Vs CPS/Histopathology is $74 \%$ vs. $54 \%$. Ki 67 and p16INK4a were used whenever sample was sufficient. Conclusion: In the present study we found that cell blocks prepared from the LBC specimens aid in the diagnosis of neoplastic lesions of cervix and are particularly valuable in distinguishing carcinoma cervix from intraepithelial lesions. Cell blocks can be further subjected to ancillary tools like immunohistochemistry and HPV- DNA testing.
\end{abstract}

Key words: Cell block, MLBC, Carcinoma cervix

\section{Introduction}

Cervical cancer is the most common incident cancer among women worldwide, taking second place only to breast. Early changes in the cervix, specifically cervical intraepithelial neoplasia (CIN), can be detected years before invasive carcinoma develops, through various strategies that target women $>30$ years for effective screening and treatment. The Papanicolaou (pap) smear consists of collection of cells from squamocolumnar junction. It is responsible for decreasing the incidence of and mortality rate from cervical cancer $[1,2]$.

Cell blocks and liquid-based cytology (LBC), are used in combination with routine cytology smears. LBC yields a thin layer of cells dispersed over a fixed area. $[3,4]$. Several reports have discussed its benefits to cytologic diagnosis, in most of these reports, a

Manuscript received: $10^{\text {th }}$ March 2018

Reviewed: $20^{\text {th }}$ March 2018

Author Corrected: $27^{\text {th }}$ March 2018

Accepted for Publication: $31^{\text {st }}$ March 2018 significant rise in sensitivity was achieved with liquidbased procedures, without major losses in specificity $[5,6]$. When adequately cellular, cell blocks serve as a source of ancillary techniques special staining, immunostaining, ultra-structural analysis, and molecular testing. Cell blocks do not require additional validation and can be preserved like routine histopathology blocks and can be processed for future diagnostic and research purposes [7].

Here we present a similar study where in the cell blocks are prepared by adding equal amount of cell block fixative to the deposit got during manual liquid-based cytology (MLBC) procedure.

The diagnostic aid and accuracy of cell blocks is studied and evaluated.Cell blocks were subjected to ancillary techniques whenever required. 


\section{Original Research Article}

\section{Objectives of the Study}

The aims and objectives of the study are:

1) To determine the utility of cell blocks prepared from liquid preparations.

2) To correlate these cases with histopathology wherever possible.

3) To determine the use of cell blocks in ancillary techniques.

\section{Methodology}

Place of study: JSS Medical College, a constituent of JSS University, Mysore.

Type of study: Prospective study

Sampling methods: Liquid based samples were collected from the transformation zone of the cervix by a plastic Ayre's spatula by $360^{\circ}$ rotation around the cervix.

Sample collection: All the patients were clinically examined in detail according to the proforma and details of other relevant laboratory investigations were collected only if necessary. For conventional pap smears, the Sample was transferred on a clean glass slide and fixed by a spray fixative. Smears were stained by Papanicolaou (pap) stain.

Cell block preparation: For cell blocks, secondrotation was taken and this sample was transferred to the liquid fixative. The sample was collected and mixed with equal parts of fixative. It was centrifuged at $2000 \mathrm{rpm}$ for 5 minutes. The supernatant was decanted, and excess fixative was blotted.

1-2 $\mathrm{ml}$ of polymer solution (containing $2 \mathrm{gm}$ of agarose, $10 \mathrm{ml}$ of polyethylene glycol, $2 \mathrm{ml}$ of poly-L-lysine and $88 \mathrm{ml}$ of distilled water) was added to the deposit obtained after centrifugation. This mixture was again centrifuged at $2000 \mathrm{rpm}$ for 5 minutes. This deposit was pipetted in a circular motion on to a glass slide. The LBC slides were prepared by indirect heat fixation (placed on a metal tray and dried in an hot air oven at 50 degrees) and further fixed by dipping in $95 \%$ alcohol for 5 minutes.

The cell block were prepared by adding equal amount of cell block fixative (10\% formalin and $95 \%$ alcohol) to the liquid deposit.

Fixation of smears: Spray fixatives were used to immediately fix the smears and to protect the smears from drying by forming an invisible film on the surface of the slides and sprayed immediately after processing of smears.

Staining: Smears stained with the conventional Pap stain. The cell block obtained is routinely processed as a histopathological tissue and stained with routine hematoxylin and eosin stain. The conventional smears, MLBC smears and cell blocks were screened and compared.

The Bethesda system 2001 was used for reporting cervical cytology for both groups. Cyto-histologic correlation was done in those cases in which a colposcopic biopsy was also done. Whenever possible, ancillary techniques were applied. In the present study ki 67 and p16 markers were done on cell block preparations.

Inclusion Criteria- Samples were collected from about 60 patients with gynaecological complaints like white discharge $\mathrm{P} / \mathrm{V}$ and bleeding $\mathrm{P} / \mathrm{V}$, attending the gynaecology out-patient clinic. Patients were in the age group of 20 to 70 years.

Exclusion Criteria- All the unsatisfactory and inadequate samples of manual liquid-based cytology sent with conventional pap smears.

\section{Statistical Methods}

All the statistical calculations were done through SPSS for windows (v 16.0)

\section{Results}

Study design: The present study was undertaken to prepare cell blocks from liquid based cytology specimens. Cell blocks were correlated with histopathology wherever possible.

Cell blocks were subjected to P16 and Ki67 in pre-neoplastic and neoplastic conditions, were material was adequate.

Age: Age group of patients ranged from 20 years to 60 years with the youngest patient aged 23 years and oldest 55 years.

Mean age was 35.9 years. Majority of the patients were in the age group of 36-45 years. 


\section{Original Research Article}

Table-1: Age-wise distribution of cases.

\begin{tabular}{|c|c|c|}
\hline Age Group & Number of cases & Percentage (\%) \\
\hline$<25$ & 08 & 14 \\
\hline $26-35$ & 22 & 36 \\
\hline $36-45$ & 23 & 38 \\
\hline $46-55$ & 07 & 12 \\
\hline Total & $\mathbf{6 0}$ & $\mathbf{1 0 0}$ \\
\hline
\end{tabular}

Distribution of cases into neoplastic and non-neoplastic diagnosed on cell block: Of 60 cases in our study, 10 cases had no deposit and cell block diagnosis could not be offered. This inadequate material may be due to sampling errors. Of the rest 50 cases with adequate material 7 were neoplastic and 43 were non- neoplastic.

Cytology: Of 60 cases of conventional pap smears, majority were inflammatory (17 cases) and NILM (17 cases), other cases included BV(4 cases), TV( 5 cases), HSIL ( 3 cases), LSIL ( 2 cases), AGUS ( 1 case), atropic ( 1 case), leptothrix (1 case), herpes ( 1 case) HPV( 1 case) and 7 cases were unsatisfactory.

MLBC: LBC smears were done for 39 cases. 2 cases had inadequate material. For 21 cases, we processed entire MLBC material from the liquid fixativefor cell blocks preparation without preparing LBC smears, to obtain adequate material for cell blocks. Of 39 LBC smears, majority of the cases were diagnosed as inflammatory (13 cases). Other cases included NILM (12 cases), TV (1 case), BV (3 cases), atropic( 2 case),HPV (1 case), LSIL ( 2 cases) and HSIL ( cases).

Cell block: 43 non-neoplastic lesions include chronic polypoid endocervicitis (CPEC- 10 cases), Koilocytes ( 3 cases), chronic cervicitis (12 cases), normalstudy (10 cases), acute on chronic cervicitis ( 7 cases), only hemorrhage (1case). Neoplastic lesions included squamous cell carcinoma SCC (1 case), dysplasia (2 cases), carcinoma in situ (4 cases). Table 2 summarizes the cases diagnosed on conventional smears, MLBC and cell blocks.

Table-2: Distribution of cases diagnosed on CPS, MLBC and Cell blocks.

\begin{tabular}{|c|c|c|c|c|c|c|}
\hline SL.No & CPS diagnosis & $\begin{array}{l}\text { No of } \\
\text { cases }\end{array}$ & $\begin{array}{c}\text { MLBC } \\
\text { Diagnosis }\end{array}$ & $\begin{array}{l}\text { No of } \\
\text { cases }\end{array}$ & $\begin{array}{l}\text { Cell block } \\
\text { diagnosis }\end{array}$ & No of cases \\
\hline 1 & HISL & 2 & HSIL & 3 & $S C C$ & 1 \\
\hline 2 & LSIL & 2 & NILM & 11 & CIN 3 & 1 \\
\hline 3 & NILM & 16 & Inadequate (IA) & 2 & CIN 2 & 2 \\
\hline 4 & US & 7 & Inflammatory & 13 & CIN 1 & 1 \\
\hline 5 & Inflammatory & 17 & BV & 3 & Dysplasia & 2 \\
\hline 6 & Bacterial Vaginosis & 4 & HERPES & 1 & $\begin{array}{c}\text { Chronic } \\
\text { cervicitis(CC) }\end{array}$ & 12 \\
\hline 7 & Herpes & 1 & TV & 1 & CPEC & 10 \\
\hline 8 & HPV & 1 & HPV & 1 & Normal study & 10 \\
\hline 9 & $\begin{array}{c}\text { Trichomonas } \\
\text { vaginalis }\end{array}$ & 5 & Atropic & 2 & $\begin{array}{l}\text { Acut on chronic } \\
\text { cervicitis(ACC) }\end{array}$ & 7 \\
\hline 10 & Leptothrix & 1 & LSIL & 2 & Koilocytes & 3 \\
\hline 11 & Atropic/menopausal & 2 & & & Only hemorrhage & 1 \\
\hline \multirow[t]{2}{*}{12} & AGUS & 1 & & & No deposit & 10 \\
\hline & Total & 60 & Total & 39 & Total & 60 \\
\hline
\end{tabular}

Adequacy of samples: 10 cases of the cell block shad no deposits. Of these only 3 cases were reported as satisfactory on conventional smears and 7 cases were unsatisfactory on conventional smears and hadinadequte samples for MLBC smear. This shows that adequte sampling procedure plays a major rolefor the better results by cell blocks. Cases reported as No deposits were maximum when MLBC had inadequte material and were minimum when LBC smears were not done and sediment was directly processed for cell blocks. 


\section{Original Research Article}

Comparison of Neoplastic lesions diagnosed on cell blocks with CPS and MLBC: Neoplastic lesions diagnosed on cell blocks included, dysplasia ( 2 cases), carcinoma in situ CIN (4 cases). squamous cell carcinoma SCC (1 case). Totally 7 cases were diagnosed as neoplastic.

1 case of carcinoma in situ was unsatisfactory on CPS. 3 cases of in situ lesions on conventional smears were diagnosed as HSIL and LSIL on cell block.

HSIL diagnosed in CPS and LBC, turned out to be squamous cell carcinoma on cell block. 1case of dysplasia was diagnosed as inflammatory on CPS and MLBC and other case of dysplasia was diagnosed as HSIL on CPS and MLBC.

This shows that cellular architecture is better preserved and neoplastic lesions which are underdiagnosed on CPS, can be correctly diagnosed on cell blocks (Table 3 ).

Table-3: Comparison of neoplastic lesions diagnosed on cell blocks with CPS.

\begin{tabular}{|c|c|c|}
\hline S.L No & CB diagnosis & CPS diagnosis \\
\hline 1 & SCC & HSIL \\
\hline 2 & CIN3 & LSIL \\
\hline 3 & CIN2 & LSIL \\
\hline 4 & CIN1 & Inflammatisfactory \\
\hline 5 & Dysplasia & HSIL \\
\hline 6 & Dysplasia & LSIL \\
\hline 7 & CIN2 & $\mathbf{7}$ \\
\hline Total & $\mathbf{7}$ & \\
\hline
\end{tabular}

Comparison of cell block diagnosis with histopathology: Histopathologic correlation was obtained in 19 cases, of these 4 cases were neoplastic and 15 cases were non-neoplastic. Of 19 cases, cell block diagnosis correlated with histopathology in 14 cases.

In our study, immune histochemistry was done as an ancillary technique on suspicious cases. Stains used were p16INK4A and ki 67(MIB1). p16 was positive in CIN and SCC.

There were significantly higher number of ki positive cells were found in HSIL, with full thickness staining and in cases with normal study, staining was confined to basal one third.

Statistical analysis: Sensitivity, specificityand positive predictive value of conventional smears, LBC smears and cell blocks were calculated and compared (Table 4).

Table-4: Sensitivity and Specificity of cell blocks, MLBC and CPS in diagnosis of neoplastic lesions

\begin{tabular}{|c|c|c|c|}
\hline Method & Sensitivity (\%) & Specificity (\%) & Positive predictive value (\%) \\
\hline Cell Block & 75 & 93 & 75 \\
\hline LBC & 66 & 84 & 60 \\
\hline CPS & 50 & 71 & 44 \\
\hline
\end{tabular}

All the statistical calculations were done through SPSS for windows (v 16.0)

Efficacy of cell blocks in the diagnosis of neoplastic lesions: $89 \%$

$P$ value $<0.001$ which is significant. 


\section{Original Research Article}

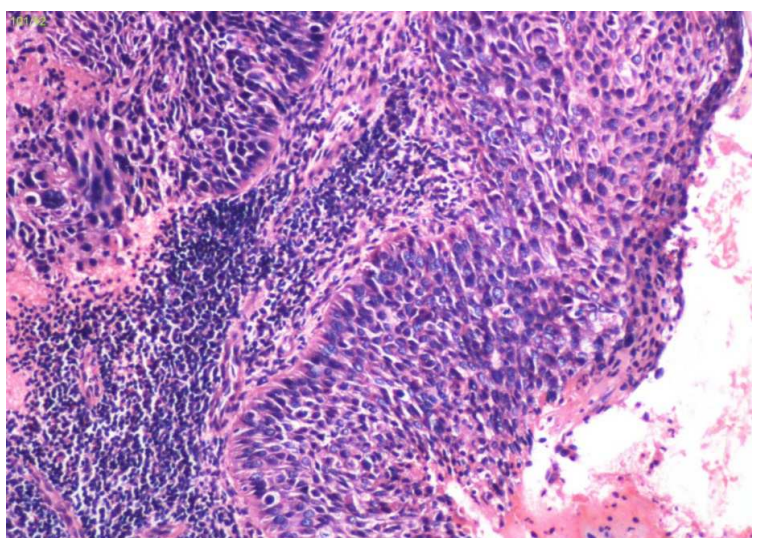

Fig-1: Cell block. (H \& E, 40X).CIN 3: Section studied shows stratified squamous epithelium displaying full thickness dysplasia and areas of inflammatory cellinfiltrate.

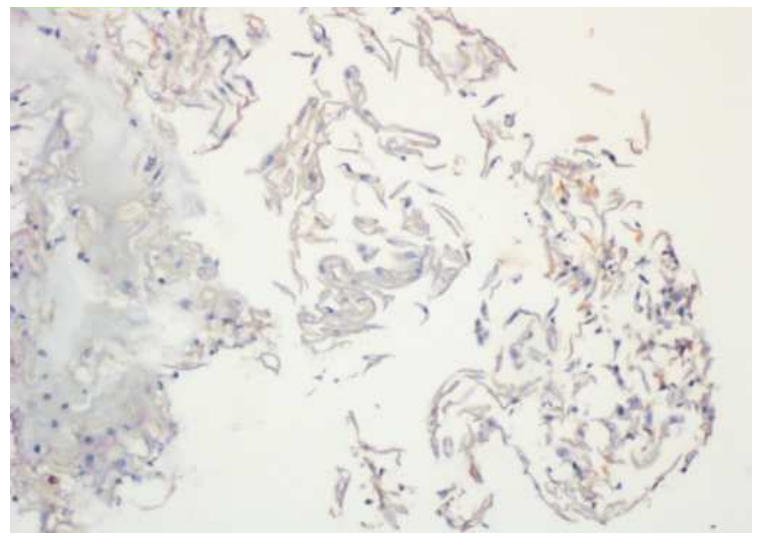

Fig-3: p16 (10 X). Normal cervix with negative p16 staining

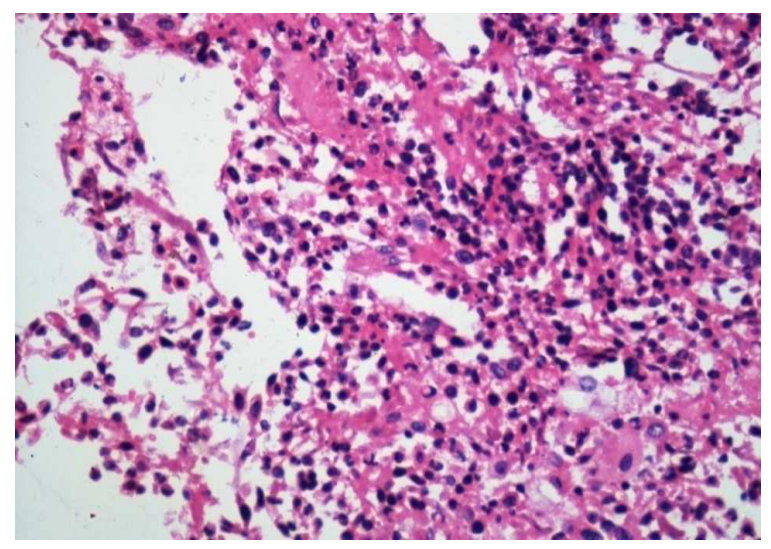

Fig.-2: Cell Block (H \& E, 40 X)- Squamous cell carcinoma-Section shows a tumor displaying features of squamous cell carcinoma.

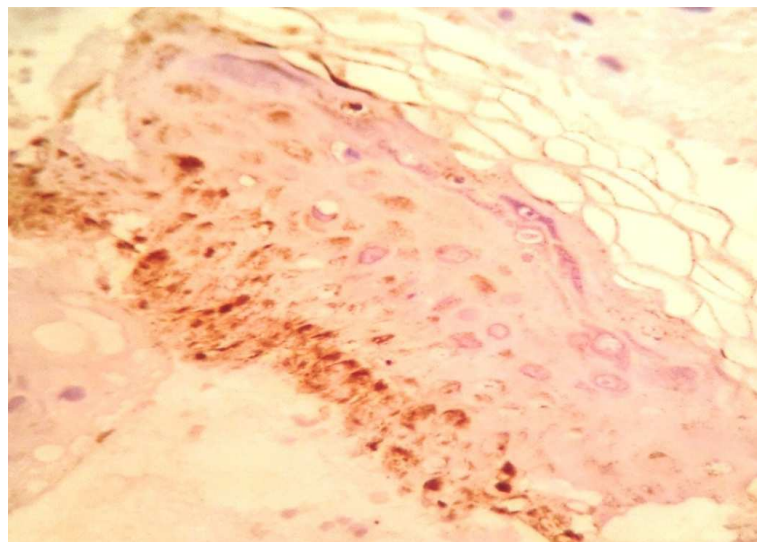

Fig-4: p16 (10 X) -HSIL Section shows p16 staining more than half of the epithelium

\section{Discussion}

The study focuses on utility of liquid-based cytology and its use for further processing of cell blocks in gynaecologic cytology.In our study the mean age range of neoplastic lesions was 40 years which is comparable toa study by Wei Q et al in which the mean age of HSIL patients was 42.2 years and that of SCC patients was 45.4 years. Unlike many other cancers, cervical cancer occurs early and strikes at the productive period of a woman's life and only 5\% of women in developing countries undergo cervical screening compared with 40-50\% in the developed world [1]. Despite the effectiveness of yearly Pap smear screening for pre-malignant lesions, Pap smears sometimes do fail and approximately $50 \%$ of the women who develop carcinoma of the cervix will have no abnormal cells on the smears, these may be attributed to sampling errors like incomplete sampling of the transformation zone, a poorly prepared slide with drying artefact or clumping of cells or interpretive errors [8].

Liquid-based cytology system has helped to overcome many of the pitfalls of the conventional Pap test. One way to recognize the different appearances of cells in the liquid-based system is to look at paired split-sample cases and to perform cell block sections of residual materials in the samples [9]. In our study we have compared conventional pap smears (CPS), MLBC smears and cell block findings. We found that sensitivity and specificity of MLBCwas higher as compared to conventional smears.

In our study even the detection rates of LSIL was better with MLBC as compared to CPS. The possible explanations for improved sensitivity of MLBC may be improved sample collection, reduction in obscuring elements and better preservation of abnormal cells on the slide allowing for more definitive categorization of abnormal cells as intraepithelial lesions. The false negative outcomes of CPS appear either due inadequate removing device, obscuring elements, and the false positive ones may be due to air drying artefacts of the smears [10,11].

Pathology Update: Tropical Journal of Pathology \& Microbiology Available online at: www.pathologyreview.in 211 | P a g e 


\section{Original Research Article}

In our study, 10 of the samples had no deposits on cell blocks due to low cellularity. It is difficult to achieve adequate cellularity within the cell block sections because liquid based cervicovaginal specimens are relatively less cellular than their non-gynaecologic counterparts with many individual scattered cells [11]. In few of our cases we entirely processed the material of MLBC without splitting the specimen, which yielded better results. Similar findings were found by George M V et al [12] and by Gangane $\mathrm{N}$ et al [13].

This problem of inadequate cellularity can be evaluated by using following features [12].

1. Concentration and alignment of singly scattered cells in a narrow plane adjacent and parallel to the cutting surface of the cell block.

2. Inclusion of a beacon-like dark AV-marker as a signpost.

Diagnostic aid and accuracy of cell blocks: In present study $14 \%$ of cases were diagnosed as malignant and $86 \%$ of cases were benign which is consistent with study by Gangane $\mathrm{N}$ et al [13]. We found that cell block showed an increase in both sensitivity and specificityin the diagnosis of neoplastic conditions of cervix, which is consistent with study by Rofagha KS et al [8], Wei Q [14], Catteau X et al [15] and Gupta S et al [16](Table 5)

Table-5: Sensitivity and specificity of cell blocks in diagnosing neoplastic lesions of cervix

\begin{tabular}{|c|c|c|}
\hline Authors & Sensitivity (\%) & Specificity (\%) \\
\hline Rofagha KS [8] & 50 & 100 \\
\hline Wei Q et al [14] & 86.3 & 100 \\
\hline Gupta S et al [15] & 87.5 & 100 \\
\hline Catteau X [16] & 50 & 100 \\
\hline Present study & 75 & 93 \\
\hline
\end{tabular}

The increased sensitivity of cell blocks in the diagnosis of malignant conditions of cervix may be due to better preservation of cytomorphologic features (like cell balls, papillae and three dimentional cluster), better staining characteristics of the nucleus, nucleoli, and cytoplasm, clear recognition of nuclear and cytoplasmic features. The tissue fragments can easily be interpreted in a biopsy-like fashion [15,17]. In the present study, one case which was diagnosed as HSIL turned out to be SCC in cell blocks and a case of inflammatory smear in pap was reported as dysplasia in cell blocks.

Cell blocks also agreed with histopathology in $74 \%$ of cases as compared to $64 \%$ in case of pap smears. The sensitivity and specificity of Pap smear remains low evenin the hands of experts, inter-observer variability still is significant and an irreducible false-negative rate inherent in the process [18]. Similar findings were found in a study, in which the tissue, cytology, and cell block findings were concordant in 15 cases (28\%). Tissue agreed more closely with the cell block than with the cytology in eight cases, and more closely with the ThinPrep cytology $[18,19]$. It was believed that in most of the specimens, the discrepancy between findings in cytology samples and findings in cell blocks was attributable to the lack of diagnostic cells in the residual material from which the cell blocks were prepared [19]. Therefore, the use of cell blocks as an adjunct to the diagnosis of challenging cytologic cases has the potential to reduce the rate of both falsepositive and false-negative results with the Pap test.

Ancillary techniques on cell blocks: In our study, immunohisto chemistry was done on suspicious cases. Stains used were p16INK4A and ki 67(MIB1). For p16INK4a, nuclear or nuclear and cytoplasmic staining was considered to be indicative of positivity, whereas for Ki-67, only nuclear staining was considered to be indicative of positivity. The percentage of positively stained cells and the number of positive cells were highest in CIN and SCC. p16 expression increased as the grade of the tumor increased SCC $>$ CIN3 $>$ CIN2 $>$ CIN1. P16 was positive in HSIL for thickness, this helped to differentiate it from SCC.p16 has excellent inter- and intra observer reproducibility and several studies have demonstrated the effectiveness of p16 ink 4 a for improving the cytological detection of HSIL in either LBC or cell block preparations [20]. In our study significantly, higher number of ki-67 positive cells were found in HSIL, with full thickness staining and in cases with normal study, staining was confined to basal one third. The "positive" Ki-67 stain is defined as one that showed positive nuclei extending above the basal one-third of the epithelium. These findings were consistent with studies by, S Sahebali et al [20] Zeng Z et al [21]. 


\section{Original Research Article}

Cell blocks are helpful in the diagnosis of precursor lesions, help to reclassify the lesions and patient follow-up and management. It can be useful in resolving diagnostic problems, such as the differentiation of squamous metaplasia or atrophy from squamous epithelial lesions of the cervix particularly when attempting to distinguish low-grade SIL or HPV effect from reactive changes [21]. Pap test alone has diagnostic limitations and Immunocytochemical analyses been used as supportive tools in the diagnosis of cervical lesions and the CB provides ease of rapid evaluation and appropriate material for the advanced [20,21].

\section{Pit falls of cell blocks in gynaecologic cytology}

1.The limitations are due to splitting the sample, due in part to the centrifugation steps used in the preparation of cell blocks. This leads to sample inadequacy.

2. Increased turn over time.

\section{Conclusion}

The cell blocks prepared from MLBC specimens increase the diagnostic accuracy of pap smears. Cell blocks not only reduce both the false positives and false negatives but also augment the sensitivity of smear tests. In diagnostic cytology, it has been advocated that ancillary molecular techniques will improve cytopathological diagnosis and may predict clinical course, however these techniques can be applied only if a sufficient number of preparations are made from a single cell sample.

Characterisation of some lesions which may be difficult in the cytology smears, may be facilitated by the histologic sectioning of the cell blocks. The disadvantages lies in the sample collection, increased turn over time and additional costs for immunohistochemistry.

Contribution of cell blocks in diagnostic cytopathology: Cell blocks are integral part of cytology. With proper specimen procurement, advanced laboratory techniques and triage they can add a valuable diagnostic adjunct to cervical smears. Cell blocks are also cost effective and can be used for molecular testing, immunohistochemistry and HPV testing. Thus, they provide resourceful material with minimal procedure, simultaneously avoiding biopsy load.

Contribution by authors: Study concept, sample collection, sample processing: Dr Shweta, Dr Nandini Manoli, Dr Nandish Manoli.

Manuscript writing: Dr Shweta, Dr Nandini Manoli. Manuscript editing, final review: Dr Shweta.

Funding: Nil, Conflict of interest: None initiated Permission from IRB: Yes

\section{References}

1. Cooper D, McCathran C.Cervical Dysplasia. Stat Pearls Publishing; 2017 May 11.
2. Kavatkar AN, Nagwanshi CA, Dabak SM. Study of a manual method of liquid-based cervical cytology. Indian J Pathol Microbiol. 2008 Apr-Jun; 51 (2) : 190-4.

3. Alves VA, Bibbo M, Schmitt FC, Milanezi F, Longatto Filho A. Comparison of manual and automated methods of liquid-based cytology. A morphologic study. Acta Cytol. 2004 Mar-Apr; 48 (2): 187-93.

4. Lee JM, Kelly D, Gravitt PE, Fansler Z, MaksemJA, Clark DP. Validation of a low-cost, liquid-based screening method for cervical intraepithelial neoplasia. Am JObstet Gynecol. 2006 Oct; 195 (4): 965-70. Epub 2006 Apr 19.

5. Richard K, Dziura B, Hornish A. Cell block preparation as a diagnostic technique complementary to fluid-based monolayer cervicovaginal specimens. Acta Cytol. 1999Jan-Feb;43(1):69-73.

6. Nathan NA, Narayan E, Smith MM, Horn MJ. Cell block cytology. Improved preparation and its efficacy in diagnostic cytology. Am J Clin Pathol. 2000 Oct; 114 (4): 599-606.

7. Saqi A. The State of Cell Blocks and Ancillary Testing: Past, Present, and Future.Arch Pathol Lab Med. 2016 Dec;140(12):1318-1322. Epub 2016 Aug 24.

8. Keyhani-Rofagha S, Vesey-Shecket M. Diagnostic value, feasibility, and validity of preparing cell blocks from fluid-based gynecologic cytology specimens. Cancer. 2002 Aug 25; 96(4):204-9.

9. Yeoh GP, Chan KW. Cell block preparation on residual ThinPrep sample. Diagn Cytopathol. 1999 Dec; 21 (6):427-31. 


\section{Original Research Article}

10. Díaz-Rosario LA, Kabawat SE.Performance of a fluid-based, thin-layer papanicolaou smear method in the clinical setting of an independent laboratory and an outpatient screening population in New England.Arch Pathol Lab Med.1999Sep;123(9):817-21.

11.Catteau X, Simon P, Noël JC. Detection of HighGrade Lesions on Cell Blocks from Residual Fluids of Pap Smears Diagnosed as Low-Grade Abnormalities: A Preliminary Pilot Study. Acta Cytologica 2012; 56: 247-50

12. George MV, ShidhamVB, MehrotraR, Amore K L, Hunt B, Narayan R.p16 ${ }^{\text {INK4a }}$ immunocytochemistry on cell blocks as an adjunct to cervical cytology: Potential reflex testing on specially prepared cell blocks from residual liquid-based cytology specimens. Cytojournal. 2011 Jan; 8:1-10.

13. Gangane N, Mukerji MS, Anshu,Sharma SM.Utility of microwave Processed cell blocks as a complement to cervico-vaginal smear. Diagcytopathol. 2007 Jun; 35 (6): 338-41.

14. Wei Q, Liu J, Zhang Z, Yang Q, Zhao T. Morphological features of cell blocks prepared from residual Liqui-PREP samples can distinguish between Highgrade squamous intraepithelial lesions and squamous cell carcinomas. Acta Cytol. 2011 Apr; 55 (3):245-50.

15. Gupta S, Halder K, Khan VA, Sodhani P.Cell block as an adjunct to conventional Papanicolaou smear for diagnosis of cervical cancer in resource-limited settings. Cytopathology. 2007 Oct; 18 (5): 309-15. Epub 2007 Aug 6.
16. Catteau X, Simon P, Noël JC. Detection of HighGrade Lesions on Cell Blocks from Residual Fluids of Pap Smears Diagnosed as Low-Grade Abnormalities: A Preliminary Pilot Study. Acta Cytologica 2012 Apr; 56 (3): 247-50.

17. Yemelyanova A, Gravitt PE, Ronnett BM, Rositch AF, Ogurtsova A, Seidman J, Roden RB. Immunohistochemical detection of human papillomavirus capsid proteins L1 and L2 in squamous intraepithelial lesions: potential utility in diagnosis and management.Mod Pathol. 2013 Feb; 26(2): 268-74. doi: 10.1038/ modpathol. 2012.156. Epub2012 Sep 21.

18. Nandini NM, Nandish SM, Pallavi P, Chandrashekhar AP, Anjali S, Dhar M Manual Liquid Based Cytology in Primary Screening for Cervical Cancer - a Cost Effective Preposition for Scarce Resource Setting. Asian Pacific J Cancer Prev. 2012; 13(8):3645-51

19. Akpolat I, Smith D, Ramzy I, Chirala M, Mody D R. The Utility of p16INK4a and Ki-67 Staining on Cell Blocks Prepared from Residual Thin-Layer Cervicovaginal Material.Cancer Cytopathol. 2004 Jun 25; 102 (3) : 142-9.

20. Sahebali S, Depuydt CE, Segers K, Vereecken AJ, Marck EV, Bogers JJ. Ki-67 immunocytochemistry in liquid based cervical cytology: useful as an adjunctive tool? J Clin Pathol .2003 Sep; 56 (9):681-686.

21. Zeng Z, Del PG, Cohen JM. MIB-1 expression in cervical Papanicolaou tests correlates with dysplasia in subsequent cervical biopsies. ApplImmunohistochem Mol Morphol .2002 Mar; 10(1):15-9.

\section{How to cite this article?}

Kulkarni S, Manoli N, Manoli N. Cell blocks prepared from gynaecologic liquid based specimens: as a source for further ancillary techniques.Trop J Path Micro 2018;4(2):207-214.doi: 10.17511/jopm.2018.i2.16 